\title{
直売所への参加が農家の生産と今後の意向に与える影響
}

Effects of local farmer's market on farmers for production and future plan

\author{
益崎慈子* 山路永司* \\ Chikako MASUZAKI, Eiji YAMAJI \\ (*東京大学大学院 新領域創成科学研究科) \\ ( ${ }^{\star}$ Graduate School of Frontier Sciences, The University of Tokyo)
}

I はじめに

農業振興や地域振興の切り札として, 全国各地で直売 所の数は増加している。2005 年農林業センサスによると 全国で 13,000 ケ所以上の直売所が存在して抢り，地域 によっては, 直売所同士の競合が発生し, 近年は, 直売 所間競争が激しくなってきている゙。

これまでの研究により，農産物直売所は，経済的な効 果だけでなく, 消費者と生産者,農家間の交流を促進する 機能 $^{2)}$ や農家間の結びつきが営農意欲向上に資する機能 3) など様々な側面から検証されてきた。これらの研究の 多くは, 農村部に立地している直売所が対象となってい たが，今日では都市部においても大小様々な直売所が開 設されてきており，それらを対象とする研究も必要とさ れている。

都市部の農家の特徴として, 生産地でありながら消費 地でもある立地を生かし，JA や直売所に限らず，ス一 バーや自家直売, 様々な市場など, 多様な販売経路を有 しやすいことが挙げられる。また専業農家から小規模な 農地で趣味的な農業を行う人まで多様な農業者がいるこ とも特徵である。さらに都市部の農業は, 農業従事者の 高路化や担い手不足に加えて, 高額の税金や宅地化の進 行による営農環境の悪化などの問題を抱えている。この ような中で多様な農業者が集まる都市部において大規模 直売所が, 地域の農業振興に果たす役割は大きいと思わ れる。

そこで本研究では，都市部の専業農家が，直壳所をな ぜ出荷先として選び，出荷者の直売所参加前後で出荷先 にどのような変化がもたらされたのかを明らかにする。 さらに専業農家の生産に対する姿勢や取り組みにどのよ うな変化を与えているのかを明らかにすることを目的と した。
調査対象とする出荷者を専業農家に設定した理由は， 大型直売所にとって安定した出荷量を確保するためには 専業農家の参加は不可欠であると考えたためである。ま た, 対象とする直壳所は, 直売所への参加によって農家 の生産意向や生産品目に起きた変化を明確に観察するた めに，設立からある程度時間が経過している大型直売所 であること, 専業農家の参加がみられること, 都市化し た地域でありながら, 生产地として活発な農業が行われ ている地域であるという3 点から千葉県柏市にある農産 物直売所 $\mathrm{A}$ （以下 $\mathrm{A}$ と記す）を選定した。

\section{II 調査対象の概要と研究の方法}

\section{1 千葉県柏市の概要と立地条件}

Aの立地する柏市は, 千葉県北部に位置しており, 市域 の大半は下総台地と谷津田から形成されている。2005 年 3 月に隣接の沼南町と合併し, 人口約 39 万人の中核 市となった。市全域が都市計画区域であり，市街化区域 と市街化調整区域は各々 $47 \%, 53 \%$ ある。JR 柏駅を中 心とした都市が形成されているが,近年では2005 年 8 月 に開通したつくばエクスブレスの沿線においても開発が 進んでいる。

2005 年現在で, 総農家数は 1,933 戸 (うち専業農家 362 戸，第 1 種兼業農家 350 戸）である。都市化の影響 もあり, 農家数,農地面積ともに年々減少傾向にあるもの の,カブやネギ,ホウレンソウは全国的な産地として有名 であり，カブは全国 1 位の生産を誇っている゙。また, 利根川治いの遊水地には水田が広がり,市内にはナシや イチゴなどの果樹園も多く存在している都市農業地帯で ある。市内には, 庭先販売から大規模な直売所に至るま で様々な直売所が 60 以上存在している。 


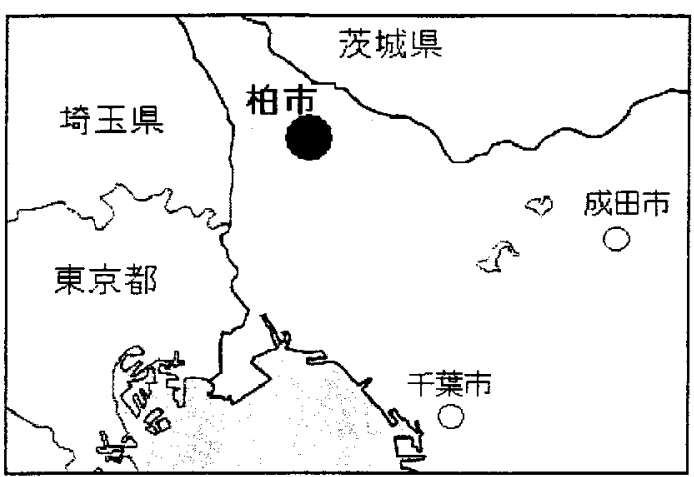

図 1 柏市の位置

Fig.1 Location of Kashiwa City

\section{2 農産物直壳所 A の概要}

A は，柏市内で農業を営む農家グループにより立ち上 げられた株式会社 B が運営母体となり 2004 年 5 月に営 業を開始した。出資者は県, 市, 投資会社, 地元 JA,

農家グループである。設立以来, 店舗の拡大や移転を行 っており, 現在の店舗面積は約 $438 \mathrm{~m}^{2}, 124$ 台の駐車が 可能である。経営理念として, 生産者と消費者の交流,

農業に関する情報の受発信基地として市民に農業への理 解を深めてもらう, 地域農業の活性化と農家の所得向上 を揭げている。

\section{表 1 農産物直売所 A の概要}

Table1 Brief overview of farmer's market $A$

\begin{tabular}{cl}
\hline 開設日 & 2004 年 5 月 \\
年間売上額 & 9 億 3 千万円 $(2008$ 年度 $)$ \\
来客数 & 50 万人 (2008 年度) \\
販売形態 & 委託販売 \\
手数料 & 農産物 $\quad 15 \% \quad$ 加工品 $\quad 20 \%$ \\
取扱品目数 & $100 \sim 120$ 品目 \\
仕入れ等 & 地元で揃えることが難しい農産物は県内 \\
& や近県の直売所と連携し, 産地限定で仕入 \\
& れる \\
\hline
\end{tabular}

2009 年 3 月現在で出荷登録は, 個人・団体合わせて 226 (個人 218 , 団体 8) である。現在も出荷希望者は増 えているが，出荷者が多く陳列スべースに限界があるた め, 新規の出荷登録者に対しては，客数が減少し始める 午前 11 時以降からの出荷のみを認めている。また, 品 目によっては，断る場合もある。

出荷者の 8 割は, 柏市内と隣接する流山市に在住して いる。そのため農地から車で 10 分〜30 分で来ることが 可能である。少数であるが，1 時間以上をかけて市外か ら通う出荷者もいる。そのような出荷者は，月に数度や
年に数回といった頻度の少ない出荷を行っている。また 県外や千葉県南部から宅配便による出荷者もいる。

農産物の出荷方法は, 毎朝出荷者が搬入し, 閉店後に 全出荷品を回収する方法を取っている。農産物の置き場 所は直売所側から品目ごとに指定されるが, 同品目内の 置き場所については，早い時間帯に直売所に搬入した出 荷者から決められていく。出荷量についての上限や下限 等の制限はない。しかし, 過剩供給を防ぎ出荷者のリス クを軽減するために, 出荷 3 日前に直売所のボードに出 荷者番号と出荷品目, 出荷予定量が各々の出荷者によっ て記入される。出荷者は事前に他の出荷者の出荷量を目 安として知ることができる。しかし，これは義務ではな いため，ボードに記入せず，また見ない出荷者もいる。 その結果として, 過剩な供給は出荷者のリスクとなる。

A は, 出荷者に対して販売状況などの情報をメールで 1 日 6 回自動的に発信している。出荷者は売れ行きなど の情報を得て追加出荷を行っている。これは農地と直売 所が近いという都市部の直売所の特徵であると言える。

販売価格は原則出荷者自身で決定できるが，極端な価 格設定に関しては，直壳所側から価格の上限，もしくは 下限を設定されることもある。多くの出荷者は同じ品目 の出荷者が定めた価格や市場価格を参考にしている。

\section{3 研究の方法}

本研究では，アンケート調査とヒアリング調査を並行 して行った。調查の実施方法は以下の通りである。

(1) アンケート実施方法

アンケート調查は，2009 年 4 月下旬から 5 月上旬に かけて出荷登録者全員に対し郵送による無記名方式で行 つた。質問項目は，フエイスシート，農業経営，出荷先 の変容, 直売所参加後の変化と Aに対する評価という構 成とした。アンアーートの回収率は $25 \%$ で, 個人出荷者で ある回答者 53 戸のうち専業農家は 21 户であった。本稿 では以下，専業農家の結果のみを用いて分析を行った。

(2)ヒアリング実施方法

ヒアリング調査は，Aの経営者（2008 年 12 月実施） と専業農家である出荷者 6 戸 (2009 年 1 月実施) に対し， 值売所にて行った。経営者へのヒアリング内容は，直売 所の概要亡出荷システム, 出荷者の出荷動问や出荷者か ら寄せられる意見，また $\mathrm{A}$ が開催する勉強会等について 伺い, 関連するデー夕の提供をお願いした。専業農家 6 戸には，農地の位置や区域区分等の情報に加え，直売所 に参加するきっかけや出荷前後の変化, 農業経営の現状 などについて同った。 


\section{III 直売所参加後の出荷先の変化}

\section{1 回答した尃業農家の属性}

直売所への出荷者のうち専業農家 21 户を抽出した。 農家の概要は，表 2 の通りである。柏市外 4 戸のうち 2 戸注柏市隣接市に居住であり,毎日 A に出荷を行ってい る。残り 2 戸は遠方であるため，宅配便による出荷をして いる。また, 21 戸の専業農家のうち, 退職後に就農した のは 2 戸である。

農地の区域区分が，市街化調整区域のみと回答した人 は水田，烟，樹園地として利用をしている。市街化調整 区域の農地は市街化区域に近く, また周囲も宅地が進行 しているところが多い。

\section{表 2 アンケート回答対象の 21 戸の専業農家の概要}

Table 2 Overview of 21 full-time farmers

\begin{tabular}{|c|c|}
\hline 年粈 & 最高㱓 78 歳, 最若齢 27 歳, 平均 56 歳 \\
\hline 居住地 & 市内：16戸，市外：4戸，回答なし：1戸 \\
\hline 出荷 & 毎日：11戸, 土日祝 0 戸, 週に数回：4戸 \\
\hline 頻度 & 月に数回 : 3 戸，年に数回 : 3 戸 \\
\hline 農地の & 市街化区域のみ：0戸，両方：7戸 \\
\hline 区域 & 市街化調整区域のみ：11戸 \\
\hline 区分 & 都市計画区域外：1戸，回答なし：2戸 \\
\hline 利用別 & $\begin{array}{l}\text { 市街化区域：畑（5）水田（1）未回答（1） } \\
\text { 市街化調整区域：畑,水田,澍園地 }\end{array}$ \\
\hline
\end{tabular}

\section{2 直売所への参加のきっかけと理由}

$\mathrm{A}$ に参加したきっかけは，「設立に関わった」と回答し た 3 戸 $(15 \%)$ と「誘ってもらった」と回答した 15 戸 (75\%) であった。また， 2 戸（10\%）は「地元 JAで 聞いた」ことが参加のきっかけとなっている。A は営業 開始にあたり地元 JA を退職した職員を店長やスタッフ として雇用し，立ち上げに至るまで事務などのシステム の立ち上げを JA と実施した。このため出荷者の募集に 際しても, 地元 JA が協力していた経緯がある。現在, 地元 JA と $\mathrm{A}$ は，集会場所の提供や出荷者が当該 JA バ ンクを利用し，売上金の振り込みが行われるなどの協力 体制がある。しかし，直売所の運営に関しては，すべて Aが独自に行って扔り JA との連携や指導などはない。

また，インタビュー調査より参加の理由として，「直 売所は売れると聞いたから」「前から直売所に出してみ たいと思っていた」という意見が多く聞かれた。農産物 の配送作業にかかる手間や負担の軽減というよりも販売 カへの期待が参加理由としてあげられた。
表 3 専業農家 21 戸の出荷開始年

Table3 Inaugural year of shipping to $A$

\begin{tabular}{cccccc}
\hline \hline 年 & 2004 & 2005 & 2006 & 2007 & 2008 \\
\hline 戸数 & 13 & 2 & 2 & 0 & 2 \\
$\%$ & 67 & 11 & 11 & 0 & 11 \\
\hline$\%$ & & & & &
\end{tabular}

\section{3 直売所に参加後の出荷先の変容}

（1） $\mathrm{A}$ 参加前の出荷先

専業農家 21 戸のうち 17 戸は市場への出荷を主として いた。17 戸のうち 10 戸は JAへの出荷のみ，もしくは 市場（柏市公設総合地方卸売市場や都内の市場）に個人 で持ち込むという出荷方法をとっていた。このような専 業農家は, カブやネギ, ホウレンソウ, コマツナなどの 少数品月に特化した生産を行う出荷者が多い。農地面積 も $20 \mathrm{a}$ から 400 a に至るまで規模は様々である。特に小 カブ専業農家は, $20 \mathrm{a}$ の農地で年に 3 度作付けを行う 1 品月に特化した農業生産を行っていた。17 戸のうち 7 戸の専業農家は, 他の直売所やスーバーに 1 2 割程度 分散して出荷していた。

他の直売所を主たる出荷先としていた専業農家は, 柏 市内の道の駅内にある農産物直壳所や，小規模の直売所 に分散して出荷を行っていた。生産品月は米やネギなど であった。

自家直売を行っている専業農家は，ナシの生産を行う 農家である。庭先での販売や，宅配便での販売を行って おり個人の顧客を有していた。

（2） A 参加後の出荷先

$\mathrm{A}$ に出荷を開始してから, 多くの専業農家の主たる出 荷先に変化が見られた。各農家の農産物売上金額に占め るAでの売上金額の割合が，5割以上と最も変化したグ ルーブを直売所型 (11 戸) とし、A での壳上金額の割合 が 2 割以上 5 割未満を併用型 (5戸)、2 割未満を市場型 (2 戸) と分類する。なお回答なしは 3 戸であった。

（i）市場型

アンケート結果より，Aには，市場出荷用に生産した 農産物を出荷している。2 戸の農家のうち 1 戸は，カブ の単品月生産を行っているカブ農家である。地元 JAに は出荷して捛らず, 都内の卸売市場に個人で持ち込むと いう出荷を行っている。Aには出荷当日の早朝に収檴し たものを出荷しているが，通年生産を行っているため， ほぼ毎日出荷している。市場出荷の配送作業にかかる時 間や負担について，夏季は都内への配送には冷蔵が必要 であるが直壳所には收椎してすぐに持ち込めるため，少 量ではあるが負担の軽減になると考えられる。残り 1 戸 
は，大規模な稲作と畑作を行い，畑地ではネギ，大根、 ホウレンソウなどを生産し，都内の市場に個人で持ち込 出出荷を行う農家である。A には数品月を出荷している。 この農家は, $130 \mathrm{a} の$ 水田で稲作を行っているが, 米は直 売所に出荷していない。Aの米出荷者による米部会は, 登録制を取っており現在 17 人が出荷している。今後も メンバーを増やす予定はない。2 戸の専業農家とも後継 者が存在し, 今後も農業を継続していく予定としている。

市場型農家へのヒアリング調査では, 直売所に参加す ることで消費者と話す機会が增えた,他の農家と知り合 いになれた, 農産物に自信がもてるようになつた,農業に 対するやる気が出たなど直売所が持つ交流の機能や意 欲の向上などの特徵を評価している。しかしながら, 市 場出荷を中心とした生産を行っているため, 直売所は補 完的な出荷先と言える。

(ii) 併用型

アンケート結果より，A 参加以前に市場への出荷を主 としていた専業農家は, $\mathrm{A} へ の$ 参加後, 若干品月数を増 やしながらAでの売上金額を伸ばしている。現在も直売 所に出荷しながら市場出荷も行っており, 出荷先は, 地 元 JA や柏市, 都内, 埼玉県内の卸売市場である。品月 にもよるが, Aへの出荷頻度が高く、「毎日」と回答した 農家がほとんどである。生産品月は葉物類が中心である。 また，これまで他の直売所やスーバーに出荷をし，また 自家直売などを行っていた農家は，Aへの出荷を増加さ せている。しかし，現在でも販売先を 2 ヶ所以上有し， 多様な出荷先を確保し, 小規模多品月の生産を行ってい る。また，ナシの生産と畑作を行っている農家は，ナシ の自家直壳に加え, 直壳所に出荷用の農産物の生産を行 っている。

併用型農家へのヒアリング調査より, 市場への出荷か ら,Aへの出荷を増やした農家法，Aが良く売れるとし， 集客力と販売力の高さを評価している。50 代で退職し後 継者となつた専業農家は, 両親が高制化し農業に従事で きなくなつた後, 一人で市場出荷用の現在の規模を保て ないと考え, 両親の引退に備えて直売所への出荷割合を 高めていた。A以外に2 2 所以上の出荷先を有する農家 については, 配送作業を家族 (妻, 息子夫妻) で行って いる。各々の取引先にも今後安定的に出荷を行う意向で ある。

併用型の専業農家は, 出荷頻度は週に 2 3 回, もし くは毎日出荷する農家であり, 直売所運営に際し, 安定 的な出荷品月と出荷量の確保に貢献していると言える。

(i i i) 直壳所型

直売所型には，退職後に就農した農家 2 戸が含まれて
いる。アンケート結果より，これまで，100\%近く市場 向けの出荷を行っていたが，Aに参加後直売所への参加 をきっかけとして，直売所への出荷に切り替えた農家が いる。これらの農家は，これまで柏市内の公設市場に出 荷していた農家である $(n=6)$ 。直売所参加前は農産物の 出荷を行っていたが, 直売所への参加をきっかけに, 自 宅に加工施設を整備し餅や等菜などの加工品出荷を始め た農家も存在する。また，市街化区域と市街化調整区域 の両方に農地を保有し, 農産物の生産を行う専業農家 7 戸のうち，6 戸はこの型に分類された。少量多品目の生 産を行っている。市街化区域で米の生産を行っている農 家は，Aの米部会のメンバーではないため，主な出荷品 月は青果類である。直売所への参加後，生産品月数を大 幅に増加させ，極めて少量多品月の生産を行っているこ 上，全員が每日出荷していることが大きな特徵である。 $\mathrm{A}$ 以外には，少量の農産物を小規模の直壳所に出荷を行 うなどしている。

直売所型農家へのヒアリング調査より, 市場への出荷 から直売所中心の出荷に切り替えた農家のうち, 市街化 調整区域で大規模な稲作を行う農家はAの米部会のメン バーである。Aでは $1 \mathrm{~kg}$ あたり 350〜380 円で販売して いるため, 手数料を引いても JA への出荷に比べて収益 は高い。17 人で年間 7000〜8000万円を売り上げており， 一人当たりの年間売上額は平均して 412〜 470 万円とい う計算となる。また, 加工品の出荷を始めた農家は, 販 売先の確保により生鮮野菜より圧倒的に収益性の高い加 工品への転換を行うことが可能になった。どの農家もA の販売力があり売上額が高いことで可能になったと評価 をしている。また，直売所型に分類されAに出荷を始め る以前から多品月生産を行い，他の小規模直壳所やスー バーに出荷していた農家は，農地が市街化区域にのみに 存在していた。生産緑地に指定し農業を続けて抢り, 後 継者も存在することから現在のところ高額な税金の心配 はない。しかし，営農を継続する上で近隣住民への配慮 から農業機械を頻繁に使うことが難しく，多品月生産が 適しているため，Aのように安定して売上が伸びる直売 所は, 重要な出荷先となっている。

\section{$\mathrm{N}$ 直売所参加後の取り組みの変化}

\section{Aヘの評価}

アンケート調査によると, $\mathrm{A} へ$ の参加後の専業農家の 評価は高い。出荷可能量に関しては，55\%（n=11）が良 いと評価し，売り場の広さは $57 \%(n=12)$ が良い上評 価している。一方で，価格の決め方については； $34 \%$ 
（n=7）が良いと評価し，47\%（n=10）が「ごちらでも ない」と回答している。

価格の決め方法出荷者の自由であるが, 各々の出荷者 が独自の基準を持っており, 同じ品目の出荷者の設定価 格を参考にするため，自由に価格設定できるとは言えな い状況にある。そのため「どちらでもない」という回答 が多いと思われる。

アンケート調査より, 図 2 に示した販売力, 集客力, 品質管理, 宣伝力の 4 項月に関しては評価が非常に高い ことがわかる。

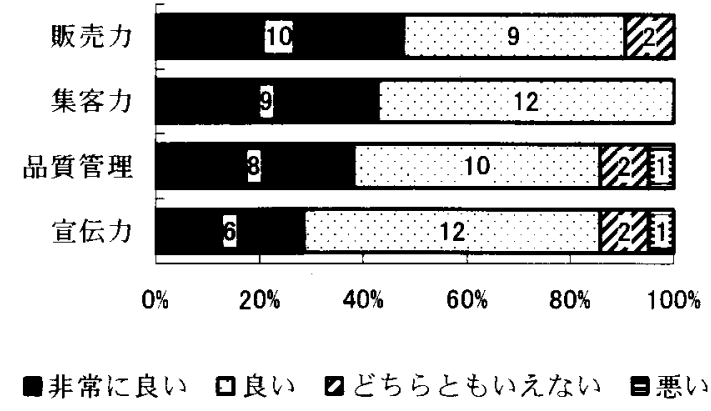

図 2 直売所への栖 $(n=21)$

Fig.2 Evaluation of $A$

販売力に関しては，インタビュー調査からも「Aなら 売れる」という声が聞かれ，主たる出荷先へ変更した農 家もいることから，売上実績への信頼は高いと言える。

$\mathrm{A}$ は 2008 年 6 月に営業開始後の来客数が 150 万人に 達した。2008 年度に哖間 50 万人の来客数を記録して おり，売り上げも 2004 年の開設以来右肩上がりに伸び, 2008 年度は 9 億门を突破している。

品質管理については, 定期的に農薬検査を行うなビ徹 底している。また, 店側の指導で生鮮野菜の品質の高さ を維持するために，青果物は $A$ 級品のみ出荷を認めてい る。通常であれば，市場に出荷できないB級品などを出 荷できることが農産物直壳所の特徽の一つと言えるが， 質の担保のためA は出荷を認めていない。出荷者の中に は，店側の出荷規定が厳しすぎるという意見が経営者に 寄せられることがあり，直売所側適宜理由の説明を行 っている。出荷を取りやめるなどの動きは今のところ見 られないため, 農家の出荷意向に与える影響はこれほど 大きくないと考えられる。

\section{2 品目数の変化}

般味で農業を行う出荷者だけでなく，専業農家でも直 売所への参加後, 直売所に出荷するために品月数を増加
させている。アンケート結果によると，直売所に出荷す るために品目数を増やした経験がある専業農家は $62 \%$ である。直売所参加後の出荷先の変化の類型別に見ると， 各々特徵が現れている。

市場型は，主として数品月に特化して市場出荷用に生 産を行っているため品月数は少ない。しかし一方で, 值 売所に出荷するための生産を行っている農家も存在して 抢り，農産物品月数は 1〜12である。インタビュ一調査 によると, 10 品目以上は手が回らなくなり策しい, とい う意見が聞かれた。

併用型は栽培品月が，5２0 品目と個人によって大き な幅がある。市場出荷と併用している農家は品月数が少 ない傾向がある。一方, 他の直売所やスーバーと併用し ている農家は, 品月数が多い。

直売所型はこの他のタイブと比べると少量多品目栽培 を行っている。出荷者によっては 100 品目に届くほど栽 培している農家もいる。ヒアリングによると, 直売所へ の参加後, 多くの品月に挑戦し，数は増やしたものの不 慣れな栽培や生産物の質が思うように保てないことから 一度增やした品目を縮小し現在の品目数と品目に落ち着 いたという声が聞かれた。また，他の出荷者との競合や これまでの試行錯誤の結果，自分の得意な品種を見抜く などして，自分の強みや得意とする品日を知り，「今後は 量を上げるより質を上げる生産をしていきたい」との意 向も聞かれた。

\section{3 研修や勉強会への参加}

アンケート調査より，57\%の専業農家が以前より研修 や勉強会に参加する頻度があがっていると回答している。 研修会の時期は不定期であり，出荷者の地域別や品目別 で開催している。内容は農薬の使用や取り組み方針など の確認である。2008 年 3 月に地元 JAでは, 出荷した小 カブで基準值を超える農薬が検出され，東京都などに出 荷された $9000 \mathrm{~kg}$ が自主回取された。とりわけカブなど のように不適切な農薬の使用が, 産地自体に影響を与え る可能性があり，農家は対策などを話し合える場所にな つている。その他の品月を生産する農家からも農業技術 向上などのために勉強会を増やしてほしいという要望が 寄せられている。

農林振興センターの指導普及員と地元 JA ヘのヒアリ ング調查によると，柏市は都内の市場までのアクセスが いいことから，個人出荷を行う人が多いという地域的特 性がある。また, 直売所など JA を通さない出荷者も多 い。そのため, 直売所が農業者の集まる新たな場所とな り技術や知識の普及が可能になることへの期待は大きい。 


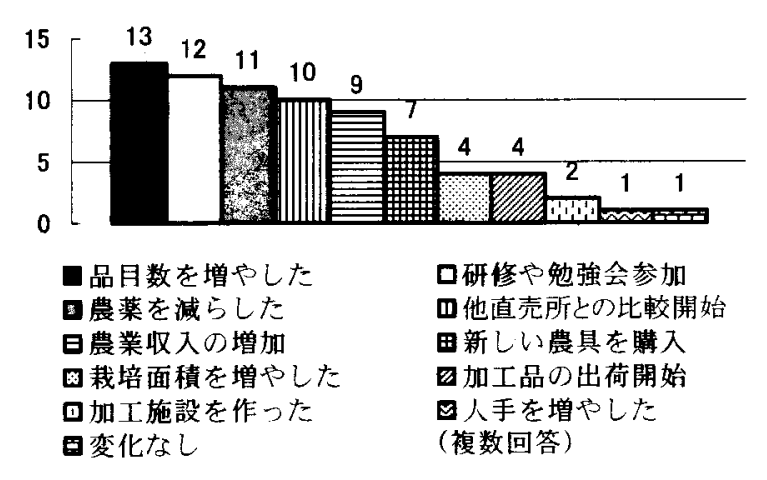

図 3 直売所に参加して見られた変化 $(n=21)$

Fig.3 The changes after enrolling $A$

\section{4 仲間作りとネットワークの形成}

アンケート調査より，「仲間ができる」ことを「非常に 良い」(n=3)「良い」(n=11)としたのは，66\%であった。 これまでの研究結果で, 直売所の交流機能が明らかにさ れてきだが，Aにおいても交流の機能が働いているこ とが確認できる。さらに, 直売所経営者, スタッフと専 業農家へのヒアリングによると，都市化の影響により農 地が隇少し，JA の経済部の規模も年々縮小している状 況で, JA へ出荷する出荷者が少ない。そのため農家は 他の農家と交流する機会が極めて少ないと考えられる。 そのため, 直売所における交流は都市化が進行する地域 においては，土地の相談など同じ悩みを抱える相談者が できることも大きいと思われる。また，後継者しして 7 年前に就農した 50 代の男性は，直売所で交流をもつた 農家から技術や知識を教えてもらう機会があり，就農の 際に抱いた知識や技術への不安が緩和したと答えている。

\section{5 今後の出荷と営農意向について}

今後の出荷については専業農家全員が継続の意向を表 明している。今後, 出荷者の高踚化が進んでいく中で,
小規模な生産でも出荷できるという直売所の長所は, 出 荷農家の状況にあっている。また $95 \%$ の農家がAに参加 して「やる気がでた」と回答するなど意欲にも慗がって いる。しかし今後の生産規模拡大への意向やそのための 労力不足改善など具体的な行動, 生産計画の変化は, 経 営上の問題や農地管理などの問題が解決されなければ難 しいと考えられる。

$\mathrm{V}$ 抒りに

本研究は, 都市部の直売所に関し，2つの月的を設定 し検証してきた。結果, 経営面については, 専業農家に とっても主たる出荷先の一つであることがわかつた。専 業農家は安定的かつ意向にあった出荷を行うためにAへ の出荷を調整しており，Aは安定した出荷のためのバッ ファ機能を有しているといえる。専業農家の生産に対す る姿勢や取り組みについては，積極的な影響を与えてい ることがわかった。また, 個人出荷が多いという地域的 特性と JA への出荷者が少ない状況の中で，A は農家の 新たな集合場所となり，情報や人的交流に寄与している。

<注躯>

注 1) 平成 17 年 農林水産省「野菜生産出荷統計」

$<$ 引用文献 $>$

1）田中满（2005）：『農産物直壳所発展のてびき』農産漁村文 化協会, 東京.

2 ）農村生活総合センター（2001）: ‘青空市・直売所の多様な 役割と運営」『生活研究レホート』52:1-109

3）飯田耕久・高橋強・林直樹（2004）：農産物直売施設によ る営農意向向上と地域の活性化効果。農村計画学会誌， (23) 別冊, 211-216

4) 小柴有理江 (2008)：地産地消の進展之農産物直壳所の課 題. 日本地域政策研究, 6 号 49-56

Summary

In recent years, local farmer's markets have had a significant influence on the shipping site of agricultural products. This study examines the contribution of farmer's markets to the improvement of the management and planning process of full-time farmers. This study suggests that farmer's markets have been welcomed by local farmers as an alternative shipping site for full-time farmers. This research found that farmer's markets encouraged full-time farmers to practice ingenuity in terms of production methods as well as introduce new products. It is further suggested that urban regions also have the capacity to build agricultural networks. 